Environment Conservation Journal 20 (1\&2) 133-138, 2019

ISSN 0972-3099 (Print) 2278-5124 (Online)

Abstracted and Indexed

\title{
Study of Aragvadha (Cassia fistula Linn.) with special reference to phyto- pharmacological properties: An overview
}

\author{
Chauhan P., ${ }^{1}$ Tiwari R. C., ${ }^{1}$ Bhutiani R. ${ }^{2} \bowtie \operatorname{and}$ Ahamad F. ${ }^{2}$
}

Received: 29.11 .2018

Revised: 28.03.2019

Accepted: 14.05.2019

\begin{abstract}
Cassia fistula Linn. is a plant of family febaceae. It is commonly known as golden shower, Indian laburnum, and rajvriksha. It has been popular as a common drug of choice for Ayurveda experts from ancient time due to its various therapeutic properties like laxative, hepato-protective, antibacterial, analgesic, antipyretic, anti-inflammatory, hypoglycemic, anticolic, antifertility, etc. and it useful in the management of many diseases like kushtha (skindiseases), jwara (febrile conditions), hridyaroga (cardiac problems), visarpa (herpes), vatarakta (gout), madhumeha (diabetesmellitus), arsha (piles), bhagandar (fistula in ano) etc. It is found in over all India and other adjacent countries, especially in Himalayan tract and outer Himalaya region. Its extract mainly contains Anthraquinone, fisulic acid, resins, flavinoids, rhein glycoside. Beside references from Ayurvedic classical texts, this article described researches which carried out on this plant for its clinical and pharmacological evaluation.
\end{abstract}

Key words: Cassia fistula Linn, anti-inflammatory, Ayurvedic formulations, Anthraquinone, madhumeha.

\section{Introduction}

Ayurveda is the collection of precious knowledge about health which was scripted by Indian Acharya thousands of years ago. It describes the use of many medicinal plants and their preparations for mitigation of diseases far before anyone else in world. It is estimated that more than $25 \%$ of the modern medicines are directly or indirectly derived from plants. Indian medicinal plants are considered as a vast source of several pharmacologically compounds that is commonly used as home remedies. C. fistula Linn. (Aragvadha) is a mediumsizedtree and its different parts are used in ayurvedic medicine as well as in home remedies (Narhari, 2003). It has been popular as a common drug of choice for Ayurvedic physicians from ancient time. C. fistulal Linn. is used as a component in many Ayurvedic formulations such as aragvadhaghrita, panchagavyaghritam, mahakalyanakaguda, siddharthakasnana, etc. Aim of this article is to provide a comprehensive

\section{Author's Address}

${ }^{1}$ Departmrnt of Agadtantra, Uttrakhand Aayurved University, Gurukul Campus, Haridwar, India.

${ }^{2}$ Limnology and Ecological Modelling Lab. Department of Zoology \& Environmental Sciences, Gurukula Kangri Vishwavidyalaya, Haridwar - 249404, Uttarakhand, India.

E-mail.:rbhutiani@gmail.com review on the phytochemical and pharmacological aspects of Cassia fistula Linn (Gupta, 2010).

Synonyms

Ayurvedic - Dirghaphala, Vyadhiha, Chaturangula,Aarveta, Karni, Karnikar, Rechan, Naradhip, Shampak, Rajvriksha, Apdhatak, Kalpadru, Swarandrum, Kritamalak, Vyadhighat, Suvarnak, Swaranang, Swarnaphala, Dhanbahera, Manthan, Nripadrum, Hempushpa, Rajtaru, Kandughana, Swarnapuspa, Kusthasudan.

English name: Indian laburnum, purging fistula, riding pipe, goldenshower, drumstick, purging cassia, pudding pipe tree.

Properties

Ayurvedic Properties of $C$. fistula Linn. are:

Rasa-Madhur, Tikta

Guna-Guru, Sheetal

Virya-Sheet

Vipaka-Madhur

Morphological description

a) Macroscopic: It is a flowering plant of febaceae family and commonly known as golden rain tree, cana fistula, and other names. The species is native to the Indian subcontinent and adjacent regions of South-east Asia. It is the state flower of Kerala and a very important ornamental plant of India. It is a 
national tree of Thailand and the National flower of Thailand. It is a small to medium-sized tree that typically grows upto 30-40 feets tall in height. It has greenish Grey smooth bark when young and rough when old it exfoliates in hard black scales. It is well known for producing five-petaled, bright yellow flower in 8-18 inches pendulous terminal racemes which covers the tree with profuse bloom in May-July. It have even pinnate compound leaves which upto 12-16 inches long and 4-8 pairs of ovate -lanceolate leaflets found in a leaf. Leaves usually drop in April as an overture to flowering which occurs from May to early July.

Tree is often considered to be semi- deciduous or semi-evergreen because of this brief loss of leaves. A second less significant bloom occur in month of September. Following flowers there is a 30 to 60 $\mathrm{cm}$ long, cylindrical, pendulous, almost straight, smooth, shining, dark brown, indehiscent pod with plentiful (40-100) horizontal seeds immersed in a dark coloured sweetish pulp. Firstly pods are green but on maturity they turn in black colour remaining on the tree until the following year. Sticky brown pulp inside the pods has been used in herbal medicines.Seeds are generally ovate, thick, smooth and dark brown or black in colour (Kirtikar and Basu, 2006).

\section{Microscopic:}

Root: Outer region of cork consisting of 30-40 rows of slightly thick walled tangentiallyelongated cells, mostly filled with brownish tannin. Centre of the root is occupied by thewood which is composed of vessels, xylem fibers, wood rays and xylem parenchyma (Rajagopal et al., 2013).

Stem: Outermost layer of cork consisting of 18-24 rows of slightly thick walled tangentially elongated cells, filled with brownish tannin. Vessels are pitted with simple perforations, fibers highly thick walled, xylem parenchyma filled with simple and compound starchgrains (Bahorun et al., 2005).

Leaf: An upper and lower epidermis, cholenchyma and a ring of pericyclic fibers enclosing a peculiarity arranged vascular bundle and small central pith, which is irregular shaped.

Fruit: The macerated material of fruit shows vascular elements composed of tracheids, small ray cells with simple pits on walls, fibers, stone cells of varying shapes and parenchymatous cells of fruit pulp filled with a brownish black content.
Table 1.Taxonomic Classification (Danish et al., 2011)

\begin{tabular}{|l|l|}
\hline Kingdom & Plantae - Plants \\
\hline Subkingdom & Tracheobionta - Vascular plants \\
\hline Division & Mangoliophyta - Flowering plants \\
\hline Class & Magnoliopsida- Dicotyledons \\
\hline Sub class & Rosidae \\
\hline Order & Fabales \\
\hline Family & $\begin{array}{l}\text { Fabacae (caesalpiniaceae) - Pea } \\
\text { family }\end{array}$ \\
\hline Genus & Cassia L. - Cassia \\
\hline Species & C. Fistula Linn. - Golden shower \\
\hline
\end{tabular}

Table 2. Showing chemical constituent of Aragvadha (Chopra et al., 2006 and Lee et al., 2001).

\begin{tabular}{|l|l|}
\hline Part & Chemical constituents \\
\hline $\begin{array}{l}\text { Bark and heart } \\
\text { wood }\end{array}$ & Barbaloin and rhein, fistucacidin \\
\hline Leaves & $\begin{array}{l}\text { Rhein and its glycoside sennosides } \\
\text { A and B }\end{array}$ \\
\hline Stem bark & $\begin{array}{l}\text { Lupeol, B-sitosterol, hexacosanol } \\
\text { tannin }\end{array}$ \\
\hline Pod & $\begin{array}{l}\text { Rhein,glycoside,fistulicacid,Ceryl } \\
\text { alcohol, anthraquinone and tannin, }\end{array}$ \\
\hline Flowers & $\begin{array}{l}\text { Ceryl alcohol, fistulin, rhein } \\
\text { dianthroquinone glucoside }\end{array}$ \\
\hline Fruit pulp & $\begin{array}{l}\text { Proteins, carbohydrates, arginine, } \\
\text { leucine, methionine, phenylalanine }\end{array}$ \\
\hline Seeds & $\begin{array}{l}\text { Galactomannam composed of D- } \\
\text { galactose and D - mannose }\end{array}$ \\
\hline Plant & $\begin{array}{l}\text { Seven bioflavonoid and two tri } \\
\text { flavonoids }\end{array}$ \\
\hline
\end{tabular}

\section{Pharmacological behavior of Cassia fistula: Antimicrobial activity}

The methanol extract of $C$. fistula seeds was investigated for potential antimicrobial activity against different medically important bacterial, yeast and fungal strains using the disk diffusion technique. The extract had great in vitro potential of antimicrobial activities against all the tested microbial strains like E. coli, $P$. aeruginosa, $S$. aureus, S.pyogenes and the fungi $C$. albicans and $A$. niger.

\section{Antifungal activity}

Extracts of $C$. fistula leaves with acetone diethyl ether and methanol shows antifungal activity against Candida albicans. Study result show that $C$. fistula seed extract had completely inhibited the growth of $C$. albicans and also exhibited prolonged anti-yeast activity. Ethyl acetate extract of Cassia fistula flower shows antifungal activity against the 
growth of many fungi such as Trichophytonmentagrophytes, Trichophytonsimii, Trichophyton rubrum and Epidermophyton floccosum due to the presence of Rhein (Bhalodia et al., 2012; Phongpaichit et al., 2004; Duraipandiyana and Ignacimuthu, 2007).

\section{Antiviral activity}

Ethanolic extract of pod and stem bark of C. fistula were found active against Ranikhet disease virus and Vaccinia virus, Ethanol extract of fruit reported active against Foot and Mouth Diseaseirus. In aqueous hot extract of pods and leaves of $C$. fistula were examine against infectious boiverhinotracheitis virus. Result of this study suggest that pod hot aqueous extract of $C$. fistula shows dose dependent anti IBR virus activity (Shankar and Mathew, 2012).

\section{Antibacterial activity}

Extraction of $C$.fistula leaves was carried out using solvents viz. petroleum ether, chloroform, ethanol, methanol and water. Although all five extracts showed promising antibacterial activity against test bacterial species like E. coli, K. aerogenes, Protious vulgaris, and $P$. aerogense bacteria but maximum activity was observed in ethanol extract. These entire findings exhibit that the leaf extracts have broad-spectrum activity and suggest its possible use in treatment of infectious diseases (Shankar and Mathew, 2012; Vasudevan et al., 2009; Panda andPadhi, 2011).

\section{Anti- inflammatory activity}

The extract ofleaves of $C$. fistula was suggested for anti-inflammatory effects. Extracts showed DoseDependent protective effect against lipid peroxidation and free radical generation in liver and kidney homogenates which shows that $C$. fistula bark extracts possess significant anti-inflammatory properties (Bhakta et al., 1999; Ilavarasan et al., 2005). Effect and the results were compared with standard drugs (diclofenac and indomethacin).

\section{Hepato- protective activity}

Bhakta et al. (1999), investigated the Hepatoprotective activity of the n-heptane extract of Cassia fistula leaves was investigated by inducing hepatotoxicity with paracetamol in rats. The extract at a dose of $400 \mathrm{mg} / \mathrm{kg}$ body wt. exhibited orally, significant protective effect by lowering the serum levels of transaminases (SGOT and SGPT), bilirubin and alkaline phosphatase (ALP). The hepato protective activity of $C$. fistula leaves has proved protective effect analogous to that of a standard hepato protective agent (Kannampalli et al., 2007 and Bhakta et al., 1999).

\section{Antipyretic activity}

Bhakta et al. (2001), examined the significant activity of methanol extract of buds of $C$. fistula for its anti-pyretic action on normal body temperature and yeast-induced pyrexia in rats in both the models at doses of 200 and $400 \mathrm{mg} / \mathrm{kg}$. At a dose level of $200 \mathrm{mg} / \mathrm{kg}$, the extract caused significant lowering of normal body temperature up to $3 \mathrm{hr}$. at $400 \mathrm{mg} / \mathrm{kg}$ dose it caused significant lowering of body temperature up to $6 \mathrm{hr}$. The results obtained are comparable to those for paracetamol, a standard antipyretic agent. The results suggest that there exists a potential benefit in utilizing C. fistula Linn. in treating conditions associated with fever.

\section{Wound healing activity}

The methanolic extract of $C$. fistula leaves was examined forits wound healing property in the form of an ointment in two types of wound models in rats, excision wound model and incision wound model. The ointment of the leaf extract of two different concentrations (5 and $10 \% \mathrm{w} / \mathrm{w}$ ointment of leaves extract in simple ointment base) responded significantly in both models of wounds tested. The results were also comparable to standard drug, nitrofurazone, in terms of wound contraction ability, epithelizationperiod, tensile strength and regeneration of tissue at wound area. C. fistula treated rats showed better wound closure, improved tissue regeneration at the wound site and supporting histopathological parameters pertaining to wound healing (Bhakta et al., 1997 and Senthil et al., 2006).

Effect on chikungunya: The crude extract of $C$. fistula Linn. served as a potential larvicidal, ovicidal and repellent agent againstchikungunya vector mosquito (Govindarajan, 2009).

Anti-tussive activity: The methanol extract of leaves of $C$. fistula has exhibited significantantitussive agent (Bhakta et al., 1998).

Effect on fistula in-ano : Role of Aragvadhadisutra in the management of fistulain ano is found effective (Kumar, 2000).

Laxative activity: The pods and leaves contain anthraquinoneglycones and anthraquinone glycoside which act as a laxative which has been used in treditioal medicine for a long time. In-vitro effect of $C$. fistula infusion on isolated guinea-pig 
ileumstudy concluded that $C$. fistula pod in fusion possess significant dose dependent laxative activity (Akanmu et al., 2004).

\section{Effect on skin diseases}

On the basis of the results of this study it may be concluded that, the $C$. fistula is having significant effect on skin diseases due to pitta originand is safe drug of choice of purgation therapy (Kumar and Chaudhary, 2013).

Antitumor activity: The study of methanolic extract of $C$. fistula seeds prevents the growth of Ehrlich ascites carcinoma. Reports show the increased life span, viable tumor cell count and decreased in the tumor volume. Improvement in the hematological parameters like hemoglobin content, red blood cell count and bone marrow cell count of the tumor bearing mice have also been observed. Cytological studies revealed a reduction in the mitotic activity, and the appearance of membrane blabbing and in tracytoplasmic vacuoles in the treated tumor cells (Shankar and Mathew, 2012).

Antiparasitic activity: Dichloromethane extract of C. fistula fruits showed $50 \%$ effective concentration of $18.96 \mu \mathrm{g} / \mathrm{ml}$ against promastigotes of Leishmania L. chagasi. The Cytotoxicity of this substance against peritoneal macrophages resulted in an EC50 value of $42.58 \mu \mathrm{g} / \mathrm{ml}$. A more or less similar study has been done by using Hexane extract of $C$. fistula fruit that shows significant antileishmanial activity against the promastigote form of Leishmania L. Chagasi (Sartorelli et al., 2009). Antifertility activity: This is observed that Oral administration of aquasextrect of seed of $C$. fistula to mated female rates from day 1-5 pregancy at the doses of 100 and $200 \mathrm{mg} / \mathrm{kg}$ body weight resulted in $57.14 \%$ and $71.43 \%$ prevention of preganancy, respectively, whereas $100 \%$ pregnancy inhibition was noted at $500 \mathrm{mg} / \mathrm{kg}$ body weight.This suggest a mild estrogenic activity of the extract (Vijay et al., 1999; Rajesh and Jain, 2009).

Antidiabitic activity: Diabetes mellitus is the most common and serious metabolic disorder among people all over the world. Methanol extract of $C$. fistula stem bark reduced the blood glucose levels in Streptozotocin-induced diabetic rats. Oral administration of Catechin a natural phenol plant secondary metabolite markedly increases tissue glycogen, restored the altered Glucokinase, glucose-6 Phosphatase, Glycogen Synthase and
Glycogen Phosphorylase. Above study suggest that Catechin possesses hypo-glycemic, Glucose oxidizing and insulin mimetic activities and hence it could be used as a drug for treating diabetes (Malpani et al., 2010; Pitchai and Manikkam, 2012; Agnihotri and Singh, 2013; Daisy and Saipriya, 2012; Jarald et al., 2013; Einstein et al., 2013; Nirmala et al., 2008).

\section{Conclusion}

A numbers of modern drugs has been isolated from the plants as plant are the natural pool of therapeutic drug free from the side effects caused by any other non-herbal product. In ancient time almost all dieses treatment managed by plant products. C. fistula is an important and potential medicinal plant. The offered literature is about the substantial evidences on the anti-bacterial activities of its pod and seed extracts C. fistula Linn. has been used since ancienttime in Ayurvedic system of medicine. It isknown as a rich source of tannins, flavanoidsand glycosides present in C. fistula Linn. might be medicinally important and/ornutritionally valuable. It possesses therapeuticpotential in diseases like kushtha (skin diseases), hridroga (cardiac problems), vatarakta (gout), raktapitta (blood disorders), madhumeha (diabetes mellitus), visarpa (herpes), and jvara (febrile conditions), etc. Though there are certain properties which are still to be screened out, almost all these utility have been revalidated through relevant experimental models in recent past. Various parts of plant are found hypoglycemic, laxative, antibacterial, antipyretic, anti-inflammatory, smooth muscle stimulant, hepatoprotective, analgesic, anticancer, abortificiant, anti-colic, anti-fertility, estrogenic, anti-inflammatory, anti-tussive, antifungal and also used to check wounds healing and antibacterial properties etc. shows us diverse veracity of the plant.

\section{References}

Agnihotri, A. and Singh, V. 2013. Effect of Tamarindus indica Linn.and Cassia fistula Linn. stem bark extracts on oxidative stress and diabetic conditions. Acta Pol Pharm, 70:1011-1209.

Akanmu, M. A. Iwalewa1, E. O., Elujoba, A. A. and Adelusola, K. A. 2004. Toxicity Potentials Of Cassia Fistula Fruits As Laxative With Reference To Senna. African Journal of Biomedical Research,7(1): 23-26. 
Bahorun, T, Neergheen, V. S. and Aruoma, O. I. 2005 Phytochemical constituents of Cassia fistula. African Journal of Biochemistry, 4(13):1530-1540.

Bhakta, T., Banerjee, S., Mandal, S. C., Maity, T. K., Saha, B. P. and Pal, M. 2001. Hepatoprotective activity of Cassia fistula leaf extract, Phytomedicine. 8(3): 220-224.

Bhakta, T., Banerjee, S., Mandal, S. C., Maity, T. K., Saha, B. P. and Pal, M. 1997. Wound healing activity of Cassia fistula Linn.(Leguminosae) leaf (methanol extract) in rats. J. Ethnopharmacol,9: 35-38.

Bhakta, T., Mukherjee, P. K., Saha, K., Pal, M.,Saha, B. P. and Mandal, S. C. 1999. Evaluation of antiinflammatory effects of Cassia fistula (leguminosae) Journal of Herbs,Spices \& Medicinal Plants, 6(4): 67-72.

Bhakta, T., Mukherjee, P., Saha, K., Pal, M. and Saha, B. P. 1998. Studies on Antitussive Activity of Cassia fistula Leaf Extract.Journal of Pharma.Bio, 36: 140-43.

Bhalodia, N. R., Nariya, P. B., Acharya,R. N. and Shukla V. J. 2012. In vitro antibacterial and antifungal activities of Cassia fistula Linn.fruit pulp extracts. AYU (An international quarterly journal of researchin Ayurveda), 33 (1): 123-129. doi: 10.4103/0974-8520.100329

Chopra, R. N., Nayar, S. L. and Chpora, I. C. 2006. Glossary of Indian Medicinal Plants, National Institute of Science Communication and Information Resources: 54.

Daisy, P. and Saipriya, K. 2012. Biochemical analysis of Cassia fistula aqueous extract and phytochemically synthesized gold nanoparticles as hypoglycemic treatment for diabetes mellitus. Int J Nanomedicine, 7:1189-1202.

Danish, M., Singh, P., Mishra, G., Srivastava, S., Jha, K. K. and Khosa, R. L. 2011. Cassia fistula Linn.(Amulthus)- An Important Medicinal Plant: a review of its traditional uses, phytochemistry and pharmacological properties, J. Nat. Prod. Plant Resour. 1 (1): 101-118.

Duraipandiyana, V. and Ignacimuthu, S. 2007. Antibacerial and antifungal activity of Cassia fistula Linn.: An Ethnomedicinal plant. Journal of Ethanopharmacology, 112: 590-94.

Einstein, J. W., Rais, M. M. and Mohd, M. A. 2013. Comparative evaluation of the antidiabetic effects of different parts of Cassia fistula Linn, a Southeast Asian Plant.J Chem,:744-763.

Govindarajan, M. 2009. Bioefficacy of Cassia fistula Linn.(Leguminosae) leaf extract against chikungunyavector, Aedesaegypti (Diptera, Culicidae), Eur Rev Med Pharmacol Sci.13(2): 99-103.

Gupta, R. K. 2010. Medicinal \& Aromatic plants, 1st edition, CBS publishers \& distributors, 116-117.
Ilavarasan, R., Mallika, M. and Venkataraman, S. 2005. Antiinflammatory and antioxidant activities of Cassia fistula Linn. Bark extracts. Afr. J. Trad., 2 (1): $70-85$.

Jarald, E. E., Joshi, S. B, Jain, D. C. and Edwin, S. 2013. Biochemical evaluation of the hypoglycemic effects of extract and fraction of Cassia fistula Linn. inalloxaninduced diabetic rats. Indian J Pharm Sci,75:427-434.

Kannampalli, P., Chandrasekaran, V. R. M., Kuppannan, G. and Sivanesan, K. 2007. Effect of Cassia fistula Linn.leaf extract on diethylnitrosamine induced hepatic injury in rats. Journal of Chemico-Biological Interaction., 167: 12 -18.

Kirtikar, K. R. and Basu, B. D. 2006. Indian Medicinal Plants, International book distributors, 2: 856-860.

Kumar, M. and Chaudhari, V. 2013. Evaluation of purgation activity of cassia fistula in skin diseases due to vitiated pitta Dosha, Journal of Ayurveda and Holistic Medicine, 1(4): $1-10$.

Kumar, P. H. 2000. Role of Aragvadhadi sutra in the management of fistula -in-ano, Ancient Science of Life, 19(3): 110-112.

Lee, C. K., Ping-Hung, L. and Yueh-Hsmng, K. 2001. The chemical constituents from the aril Cassia fistula Linn. Journal of Chinese Chemical Society, 48: 1053-58.

Malpani, S. N., Manjunath, K. P., Hasanpasha, S., Savadi, R. V. AkkiKusum, S. and Darade, S. S. 2010. Antidiabetic activity of Cassia fistula Linn. Bark in alloxan induced diabetic rats. Int. Journal of Pharm. Sciences, 2: 382-85.

Misra, T. R., Singh, R. S., Pandey, H. S. and Singh, B. K. 1997. A new diterpene from Cassia fistula pods. Fitoterapia, (58): 375.

Narhari, P. 2003. Raj Nighantu, edited by TripathiIndradeva, $3^{\text {rd }}$ Edition,ChaukambhaKrishndas Academy Varanasi: 272-273.

Nirmala, A., Eliza, J., Rajalakshmi, M., Edel, P. and Daisy, P. 2008. Effect of Hexane Extract of Cassia fistula Barks on Blood Glucose and Lipid Profile in Streptozotocin Diabetic Rats. International Journal of Pharmacology, 4(4): 292296.10.3923/ijp.2008.292.296

Panda, S. K. and Padhi, L. P. 2011. Mohanty G. Antibacterial activities and phytochemical analysis of Cassia fistula (Linn.) leaf. J AdvPharmTechnol Res, 2: 627.

Phongpaichit, S., Pujenjob, N., Rukachaisirikul, V. and Ongsakul, M. 2004. Antifungal activity from leaf extracts of Cassia alata, Cassia fistula and Cassia tora L. Songklanakarin. Journal Sci. Technology, 26: $741-48$. 


\section{Chauhan et al.}

Pitchai, D. and Manikkam, R. 2012. Hypoglycemic and insulin mimetic impact of catechin isolated from Cassia fistula: A substantiate in silico approach through docking analysis. Med Chem Res, 21: 2238-50.

Rajagopal, P. L., Premaletha, K., Kiron, S. S. and Sreejith, K. R. 2013. Phytochemical and pharmacological review on Cassia fistula Linn.the golden shower. Int J Pharm ChemBiolSci, 3:672-679.

Rajesh, Y. and Jain, G. C. 2009. Effect of Petroleum ether extract of Cassia Fistula Seeds on Uterine Histoarchitecture of Ovariectomized Female Rats. International Journal of PharmTech Research, 1(3): 438444.

Sartorelli, P., Carvalho, C. S., Reimao, J. Q., Ferreira, M. J. and Tempone, A. G.2009. Antiparasitic activity of biochanin A, an isolated isoflavone from fruits of Cassia fistula (Leguminosae).Parasitology Research, 104(2): 311314.doi: 10.1007/s00436-008-1193

Senthil, K. M., Sripriya, R., Vijaya, R. H and Sehgal, P. K. 2006. Wound healing potential of Cassia fistula on infected albino rat model. J Surg Res, 131: 283-289.

Swetha, 2009. Meiofauna in relation to sediment characteristics in Mulki estuary, Dakshina Kannada. M.F.Sc., thesis. Kar. Vet. Ani. Fish. Sci. Univ., Bidar.
Shankar, S. and Mathew, L. 2012. Chemopreventive Potential of Methanol Extract of Stem Bark of Cassia Fistula L.In Mice.IJPI'S Journal of Pharmacognosy and Herbal Formulations, 2: 8.

Tripathi, S. K., 2002. Distribution of phytoplankton in relation to hydrographic parameters of Nethravati-Gurupur estuary, Mangalore (Dakshina Kannada). M.F.Sc., thesis, University of Agricultural Sciences, Bangalore, India.

Vasudevan, D. T., Dinesh, K. R., Gopalkrishnan, S., Sreekanthc, S. K. and Shekar, S. 2009. The potential of aqueous and isolated fraction from leaves of Cassia fistula Linn as antibacterial agent. Int J Chem Sci, 7: 2363-2367.

Vijaya Kumar, S. K., Rajesh, K.M., Mendon, M. R. and Hariharan, V., 2000. Seasonal distribution and behavior of nutrients with reference to tidal rhythm in the Mulki estuary, South West Coast of India. J. Mar. Biol. Ass. India. 42: 21-31.

Ysebaert, J. D., Jones, B. H., Dickey, T. D., Brink, K. H., Weller, R. A., Marra, J. and Codispoti, L. A., 2002. The Northeast Monsoon's impact on mixing, phytoplankton biomass and nutrient cycling in the Arabian Sea. $J$. of Deep-Sea Res.,2(47): 1353-1385. 